\title{
Acute Toxicity of Endosulfan, Nonylphenol Ethoxylate, and Ethanol to Different Life Stages of the Freshwater Snail Biomphalaria tenagophila (Orbigny, 1835)
}

\author{
E. C. Oliveira-Filho, ${ }^{1}$ B. R. Geraldino, ${ }^{2}$ C. K. Grisolia, ${ }^{3}$ F. J. R. Paumgartten ${ }^{2}$ \\ ${ }^{1}$ Laboratory of Ecotoxicology, Cerrados Agricultural Research Center, Embrapa \\ Cerrados, BR020, Km 18, Cx.P. 08223, 73310-970, Planaltina, DF, Brazil \\ ${ }^{2}$ Laboratory of Environmental Toxicology, Department of Biological Sciences, \\ National School of Public Health, Oswaldo Cruz Foundation (FIOCRUZ), Rua \\ Leopoldo Bulhões 1480, 21041-210, Rio de Janeiro, Brazil \\ ${ }^{3}$ Institute of Biology, Brasilia University, Brasilia, DF, Brazil \\ Received: 20 May 2005/Accepted: 20 September 2005
}

Biomphalaria tenagophila (Mollusca; Gastropoda) is a tropical freshwater pulmonate snail widely distributed in Brazil where it is one of the intermediate hosts of Schistosoma mansoni. It is an hermaphrodite but cross-fertilization occurs as well. At $25^{\circ} \mathrm{C}$, eggs hatch between the sixth and ninth day after oviposition (Paraense 1972). Egg laying generally starts when the snails are about two months old.

Endosulfan is a cyclodiene insecticide used in agriculture and as a wood preservative. It is a potential water pollutant. Residues of endosulfan have been found in water, sediment, rainfall (Laabs et al. 2002), phytoplankton, zooplankton (DeLorenzo et al. 2002), aquatic macroinvertebrates (Leonard et al. 1999) and fish (Kole et al. 2001).

Nonylphenol ethoxylates are nonionic surfactants widely used as emulsifiers in industrial and household cleaning agents, agricultural chemicals, and plastic polymerization. High amounts of nonyphenol ethoxylates have been found in domestic sewage and industrial effluents and, where there are no sewage treatment plants, they are released directly into water bodies (Maguire 1999). Several recent studies have reported relatively high levels of nonylphenol ethoxylates in water bodies (Bennie 1999).

Ethanol is a carrier solvent frequently employed in aquatic ecotoxicity tests to dissolve chemicals that otherwise would not be soluble in water.

Data regarding the toxicity of the foregoing compounds to benthic macroinvertebrates are scarce as compared to data available for other aquatic species. Furthermore, as a rule, toxicity tests are carried out only with adult individuals. Tests to evaluate toxicity to developing embryos within the egg masses and to newly hatched snails are far less frequently conducted.

This study was performed to evaluate acute toxicities of endosulfan, nonylphenol ethoxylate and ethanol to the snail Biomphalaria tenagophila at three different life stages to determine the most sensitive stage of this important freshwater organism.

Correspondence to: E. C. Oliveira-Filho 


\section{MATERIALS AND METHODS}

Technical grade endosulfan (purity 98.7\%) was obtained from Hoeschst-Agrevo. Nonylphenol ethoxylate 9.5 (RENEX 95, nonylphenol with 9.5 ethoxylate units) was obtained from BASF Brazil. Ethanol (Pro Analysis grade, purity: 99\%) was purchased from VETEC Chemistry.

Nominal concentrations of endosulfan $(0.05 ; 0.1 ; 0.25 ; 0.5 ; 1.0 ; 2.5 ; 5.0 ; 10.0$ and $20.0 \mathrm{mg} / \mathrm{L})$, nonylphenol ethoxylate $(0.5 ; 1.0 ; 3.0 ; 6.0 ; 11.0 ; 26.0 ; 52.0 ; 104.0$; $262.0 ; 524.5$ and $1049.0 \mathrm{mg} / \mathrm{L})$ and ethanol $(0.5 ; 1.0 ; 2.5 ; 5.0 ; 10.0 ; 20.0 ; 40.0$; $80.0 \% \mathrm{v} / \mathrm{v})$ were dissolved in synthetic soft water $(\mathrm{pH} 7.1 \pm 0.1$, water hardness 40-48 $\mathrm{mg} / \mathrm{L}$ as $\mathrm{CaCO}_{3}$ ) prepared as recommended by ABNT guidelines (ABNT 2004). Ethanol, up to a maximum concentration of $0.5 \% \mathrm{v} / \mathrm{v}$, was used to dissolve endosulfan that otherwise is practically insoluble in water.

B. tenagophila snails were from the breeding stock maintained at the Department of Ecology from Brasilia University. Embryos (egg masses 0-24 hours after spawning), newly hatched (shell diameter $\pm 1 \mathrm{~mm}$ ) and adults (shell diameter 6-8 $\mathrm{mm}$ ) were exposed to test chemicals for 96 hours. Egg masses (approximately 200 eggs, from 8 to 12 egg masses, per concentration) were collected on cellophane sheets placed overnight in the aquaria where the colony was maintained. Cellophane sheets with the egg masses were transferred to Petri dishes, containing $50 \mathrm{~mL}$ of the respective chemical solution, where they were exposed to the test chemicals. Newly hatched snails ( 20 per concentration, in duplicate) were exposed to test chemicals in $250 \mathrm{~mL}$ glass beakers containing $250 \mathrm{~mL}$ of solution, and adults snails ( 20 per concentration, in duplicate) were exposed to test chemicals in $1000 \mathrm{~mL}$ glass beakers containing $1000 \mathrm{~mL}$ of solution. All beakers were covered with a net to prevent snails from escaping.

Static acute toxicity assays were performed at controlled room temperature $(25 \pm$ $2^{\circ} \mathrm{C}$ ) and light/dark cycle (lights on for 16 hours) in the absence of food. Lethality was evaluated at 24, 48, 72 and 96 hours of exposure and the $\mathrm{LC}_{50} \mathrm{~S}$ and their $95 \%$ confidence limits were calculated using the Trimmed Spearman-Karber method (Hamilton et al. 1977).

\section{RESULTS AND DISCUSSION}

$\mathrm{LC}_{50}$ values obtained for the three chemicals are presented in Table 1 . Newly hatched snails were more susceptible to the three chemicals than embryos and adult snails. The higher LC50s obtained for embryos could possibly be explained by the protection provided by the jelly mass in which eggs are embedded. Some molluscicides that are also ovicides, such as niclosamide and organotin compounds, apparently easily penetrate this mass killing the developing embryos at concentrations lower than those that are lethal to adult snails (Oliveira-Filho 2003). 
Table 1. Acute toxicities of endosulfan, nonylphenol ethoxylate and ethanol to embryos - within the egg masses, newly-hatched and adult snails of Biomphalaria tenagophila.

\begin{tabular}{|c|c|c|c|c|}
\hline \multirow[t]{2}{*}{ Chemicals } & \multirow[t]{2}{*}{ Exposure } & \multicolumn{3}{|c|}{ Life Stage } \\
\hline & & Embryo & $\begin{array}{l}\text { Newly } \\
\text { hatched }\end{array}$ & Adult \\
\hline \multirow{6}{*}{$\begin{array}{l}\text { Endosulfan } \\
\text { mg/L }\end{array}$} & 24-h & $\begin{array}{c}15.52 \\
(11.50-20.95)\end{array}$ & $\begin{array}{c}0.48 \\
(0.19-1.22)\end{array}$ & $\begin{array}{c}8.80 \\
(6.92-1121)\end{array}$ \\
\hline & 48-h & 9.58 & 0.34 & 1.77 \\
\hline & & $(7.92-11.61)$ & $(0.14-0.86)$ & $(0.93-3.41)$ \\
\hline & 72-h & 7.71 & 0.20 & 1.41 \\
\hline & & $(6.63-8.96)$ & $(0.10-0.41)$ & $(0.85-2.34)$ \\
\hline & 96-h & $\begin{array}{c}5.81 \\
(5.03-6.71)\end{array}$ & $\begin{array}{c}0.12 \\
(0.06-0.23)\end{array}$ & $\begin{array}{c}0.89 \\
(0.46-0.81)\end{array}$ \\
\hline \multirow{6}{*}{$\begin{array}{l}\text { Nonylphenol } \\
\text { Ethoxylate } \\
\mathrm{mg} / \mathrm{L}\end{array}$} & 24-h & 640.25 & 11.22 & $\begin{array}{l}35.49 \\
\end{array}$ \\
\hline & 48-h & 322.22 & 7.13 & 24.33 \\
\hline & & $(205.75-504.62)$ & $(4.52-11.26)$ & $(13.89-42.64)$ \\
\hline & 72-h & 78.43 & 4.42 & 12.56 \\
\hline & & (54.91-112.05) & $(2.59-7.54)$ & $(7.79-20.24)$ \\
\hline & 96-h & $\begin{array}{c}29.23 \\
(25.86-33.04) \\
\end{array}$ & $\begin{array}{c}1.68 \\
(0.88-3.21) \\
\end{array}$ & $\begin{array}{c}6.39 \\
(4.16-9.82) \\
\end{array}$ \\
\hline \multirow{7}{*}{$\begin{array}{l}\text { Ethanol } \\
\%(v / v)\end{array}$} & 24-h & $\begin{array}{c}40.91 \\
(32.45-51.57)\end{array}$ & $\begin{array}{c}15.87 \\
(8.79-28.65)\end{array}$ & $\begin{array}{c}33.63 \\
(18.18-62.22)\end{array}$ \\
\hline & 48-h & 27.54 & 14.14 & 18.66 \\
\hline & & $(25.50-29.74)$ & $(8.88-22.51)$ & $(12.61-27.62)$ \\
\hline & 72-h & 24.80 & 4.45 & 8.12 \\
\hline & & $(23.47-26.20)$ & $(2.77-7.18)$ & $(4.95-13.34)$ \\
\hline & $96-\mathrm{h}$ & 23.82 & 1.99 & 2.94 \\
\hline & & $(22.66-25.04)$ & $(1.28-3.10)$ & $(1.91-4.53)$ \\
\hline
\end{tabular}

Data are presented as $\mathrm{LC}_{50}(\mathrm{mg} / \mathrm{L})$ with, in brackets, their respective $95 \%$ confidence limits. Ethanol concentrations are expressed as \% (v/v) dilution.

Published data with other species report that immature stages are more sensitive than adult stages. This has been observed with other freshwater snails such as Physa gyrina (Wier and Walter 1976) and Lymnaea stagnalis (Coeurdassier et al. 2004), and insects as Chironomus riparius (Williams et al. 1986). On the other hand for life stages of the grass shrimp Palaemonetes pugio adults were more sensitive to endosulfan than larvae (Key et al. 2003).

B. tenagophila, at the three life stages, seemed to have been less susceptible to endosulfan than other freshwater species that have been tested so far. It was 
reported that fish are much more susceptible to endosulfan with $96-\mathrm{h} \mathrm{LC}_{50}$ values ranging from 0.014 to $42 \mu \mathrm{g} / \mathrm{L}$ (Sunderam et al. 1992). The estuarine amphipod Gammarus palustris was also more susceptible to endosulfan than B. tenagophila with a 96-h LC $\mathrm{LC}_{50}$ as high as $0.43 \mu \mathrm{g} / \mathrm{L}$ (Leight and Van Dolah 1999), but the freshwater crab Oziotelphusa senex senex, with a 96-h $\mathrm{LC}_{50}=15.14 \mathrm{mg} / \mathrm{L}$ (Vijayakumari et al. 1987), was somewhat more resistant than this snail.

Toxicity of nonylphenol with 9 ethoxylate units to different aquatic species was investigated by Dorn et al. (1993) They reported a $96-\mathrm{h} \mathrm{LC}_{50}$ of $4.5 \mathrm{mg} / \mathrm{L}$ for the fish Pimephales promelas, a $48-\mathrm{h} \mathrm{EC}_{50}$ of $13 \mathrm{mg} / \mathrm{L}$ for the microcrustacean Daphnia magna, and a 5 -min $\mathrm{EC}_{50}$ of $60.6 \mathrm{mg} / \mathrm{L}$ for the marine bacterium Photobacterium phosphoreum (Microtox System). In the present study $B$. tenagophila (newly hatched snails) was more susceptible to nonylphenol ethoxylate than $D$. magna $(48-\mathrm{h})$ and $P$. promelas $(96-\mathrm{h})$.

Data on the toxicity of ethanol to aquatic species are difficult to compare because, in this particular case, different exposure systems (open or closed) have been used. Since in the present study static assays were carried out using open containers (glasses or Petri dishes), and ethanol is volatile, some ethanol could have been lost during the 96 hour test period. Geraldino et al. (2004) found, for B. glabrata embryos exposed into closed Petri dishes, an ethanol $96-\mathrm{h} \mathrm{LC}_{50}$ of $0.31 \mathrm{M}$ (i.e. $14,291 \mathrm{mg} / \mathrm{L}$ or $1.43 \%$ ). In this study, for $B$. tenagophila embryos exposed into open Petri dishes, ethanol 96-h $\mathrm{LC}_{50}$ was as high as $23.82 \%$. Although a difference of susceptibilities between the two species of Biomphalaria snails cannot be entirely ruled out, the use of a closed system in the case of B. glabrata embryos - preventing the loss of the solvent - could have enhanced the toxicity of ethanol. As noted with endosulfan, in the case of ethanol, newly hatched snails were also more susceptible than embryos and adult organisms (Table 1).

Two other aquatic species data on the toxicity of ethanol are available in the literature. Ethanol was toxic, for instance, to the fish Pimephales promelas with a 96-h $\mathrm{LC}_{50}$ of $14,200 \mathrm{ppm}$ (or $1.42 \%$ ) (USEPA 1995) and to the marine alga Skeletonema costatum with a $96-\mathrm{h} \mathrm{EC}_{50}$ of $10,943 \mathrm{mg} / \mathrm{L}$ (or $1.09 \%$ ) (Cowgill et al. 1989). The LC50s obtained for the foregoing organisms are very similar to those obtained for newly hatched snails in the present study $\left(96-\mathrm{h} \mathrm{LC} \mathrm{L}_{50}=1.99 \%\right)$.

In conclusion, results from this study indicated that $B$. tenagophila snails, at the three life stages, were more susceptible to endosulfan than to nonylphenol ethoxylate and ethanol-induced toxicities. It should be noted that toxicity increased significantly at longer exposures (96 hours), suggesting that the persistence or continuous presence of these compounds in water is likely to drastically affect snails communities.

Data presented here also suggested that, as far as the three substances are concerned, newly hatched snails are more vulnerable to the toxic effects of test 
chemicals and could be a suitable life stage to evaluate adverse effects of pollutants in aquatic ecosystems.

\section{REFERENCES}

ABNT - Associação Brasileira de Normas Técnicas (2004) Ecotoxicologia aquática - Toxicidade aguda - Método de ensaio com Daphnia spp (Cladocera, Crustacea). NBR 12713, Rio de Janeiro, Brasil.

Bennie DT (1999) Review of the environmental ocurrence of alkylphenols and alkylphenol ethoxylates. Water Qual Res J Canada 34:79-122

Coeurdassier M, Vaufleury A, Scheifler R, Morhain E, Badot PM (2004) Effects of cadmium on the survival of three life-stages of the freshwater pulmonate Lymnaea stagnalis (Mollusca:Gastropoda). Bull Environ Contam Toxicol 72:1083-1090

Cowgill UM, Millazo DP, Landenberger BD (1989) Toxicity of nine benchmark chemicals to Skeletonema costatum a marine diatom. Environ Toxicol Chem 8:451-455

DeLorenzo ME, Taylor LA, Lund SA, Pennington PL, Strozier ED, Fulton MH (2002) Toxicity and bioconcentration potential of the agricultural pesticide endosulfan in phytoplankton and zooplankton. Arch Environ Contam Toxicol 42:173-181

Dorn PB, Salanitro JP, Evans SH, Kravetz L (1993) Assessing the aquatic hazard of some branched and linear nonionic surfactants by biodegradation and toxicity. Environ Toxicol Chem 12:1751-1762

Geraldino BR, Gomes-Carneiro MR, Paumgartten FJR (2004) Toxicidade de solventes para embriões de Biomphalaria glabrata. VIII Congresso Brasileiro de Ecotoxicologia, 17-20 outubro, p 63

Hamilton MA, Russo RC, Thurston RV (1977) Trimmed Spearman-Karber method for estimating median lethal concentrations in toxicity bioassays. Environ Sci Technol 11:714-719

Key PB, Chung KW, Opatkiewicz AD, Wirth EF, Fulton MH (2003) Toxicity of the insecticides fipronil and endosulfan to selected life stages of the grass shrimp (Palaemonetes pugio). Bull Environ Contam Toxicol 70:533-540

Kole RK, Banerjee H, Bhattacharyya A (2001) Monitoring of market fish samples for endosulfan and hexachlorocyclohexane residues in and around Calcutta. Bull Environ Contam Toxicol 67:554-559

Laabs V, Amelung W, Pinto AA, Wantzen M, Silva CJ, Zech W (2002) Pesticides in surface water, sediment, and rainfall of the northearstern Pantanal basin, Brazil. J Environ Qual 31:1636-1648

Leight AK, Van Dolah RF (1999) Acute toxicity of the insecticides endosulfan, chlorpyrifos, and malathion to the epibenthic estuarine amphipod Gammarus palustris (Bousfield). Environ Toxicol Chem 18:958-964

Leonard AW, Hyne RV, Lim RP, Chapman JC (1999) Effect of endosulfan runoff from cotton fields on macroinvertebrates in the Namoi river. Ecotoxicol Environ Saf 42:125-134 
Maguire RJ (1999) Review of the persistence of nonylphenol and nonylphenol ethoxylates in aquatic environments. Water Qual Res J Canada 34:37-78

Oliveira-Filho EC (2003) Efeitos de substâncias químicas sobre a reprodução de moluscos de água doce: Estudos com caramujos do gênero Biomphalaria. Tese de Doutoramento. ENSP/FIOCRUZ: Rio de Janeiro, Brasil

Paraense WL (1972) Fauna planorbídica do Brasil. In: Lacaz CS, Baruzzi, RG, Siqueira JW (eds) Introdução à geografia médica do Brasil, pp. 213-239, Edgar Blucher, São Paulo

Sunderam RIM, Cheng DMH, Thompson GB (1992) Toxicity of endosulfan to native and introduced fish in Australia. Environ Toxicol Chem 11:1469-1476

USEPA (1995) Reregistration eligibility decision for aliphatic alcohols. EPA 738R-95-013. 238p

Vijayakumari P, Reddy DC, Ramamurthi R (1987) Acute toxicity of endosulfan to crab: effect on transport property of haemocyanin. Bull Environ Contam Toxicol 38:742-747

Wier CF, Walter WM (1976) Toxicity of cadmium in the freshwater snail Physa gyrina. J Environ Qual 5:359-362

Williams KA, Green DW, Pascoe D, Gower DE (1986) The acute toxicity of cadmium to different larval stages of Chironomus riparius (Diptera: chironomidae) and its ecological significance for pollution regulation. Oecologia (Berlin) 70:362-366 